\title{
ADDITIONS TO THE FISH FAUNA OF HAITI AND SANTO DOMINGO ${ }^{1}$
}

\author{
William Beebe, Sc. D. \\ Director, Department of Tropical Research \\ and \\ JOHN TEE-VAN
}

General Associate, Department of Tropical Research

In 1927 the Haitian Expedition of the Department of Tropical Research of the New York Zoological Society, under the direction of Dr. William Beebe, spent five months in the field studying the fishes of Port-au-Prince Bay and nearby territory. The present paper completes the reports on the fishes of that expedition.

For a summary of the species of fish known from the island the reports published in ZoologicA, Vol. X, Nos. 1, 2 and 3, must be consulted and to these should be added the list of species noted in this paper. This list is composed of species reported from Haiti-Santo Domingo, the references to which had either been omitted from the previous papers or had appeared after they were issued. There is also one correction of identification, and one species added from an unpublished record.

The three published fish reports of the expedition, mentioned above, are as follows:

"The Fishes of Port-au-Prince Bay, Haiti, With a Summary of the Known Species of Marine Fish of the Island of Haiti and Santo Domingo," William Beebe and John Tee-Van, ZoologicA, Scientific Contributions of the New.York Zoological Society, Vol. X, No. 1, 1928, pp. 1-279.

"Cichlid Fishes in the West Indies with Especial Reference to Haiti, Including the Description of a New Species of Cichlasoma," John Tee-Van, ZoologicA, Vol. X, No. 2, 1935, pp. 281-300.

${ }^{1}$ Contribution No. 477, Department of Tropical Research, New York Zoological Society. 
"An Annotated List of the Cyprinodont Fishes of Hispaniola, with Descriptions of Two New Species," George S. Myers, ZooloGicA, Vol. X, No. 3, 1935, pp. 301-316.

\section{ADDITIONAL SPECIES RECORDED FROM THE ISLAND OF HAITI AND SANTO DOMINGO}

\section{Family SYNGNATHidae}

Hippocampus reidi Ginsburg

Ginsburg, I., Journ. Washington Acad. Sci., Vol. 23, No. 12, 1933, p. 561.

Mugil cephalus Linnaeus

\section{Family MugiLidae}

Fowler, H. W., Proc. Acad. Nat. Sci. Phila., Vol. 71, 1919, p. 153.

Family Centropomidae

Centropomus cuvieri Bocourt

Fowler, H. W., Proc. Acad. Nat. Sci. Phila., Vol. 58, 1906, p. 428. (This species has been synonymized with $C$. pedimacula, which in turn has been placed under C. pectinatus).

\section{Family HaEmulidae}

Haemulon album Cuvier and Valenciennes

Fowler, H. W., Proc. Acad. Nat. Sci. Phila., Vol. 81, 1929, p. 638.

Anisotremus surinamensis (Bloch)

Fowler, H. W., Proc. Acad. Nat. Sci. Phila., Vol. 81, 1929, p. 640.

\section{Family GERRIDAE}

Eucinostomus harengulus Goode and Bean

Fowler, H. W., Proc. Acad. Nat. Sci. Phila., Vol. 81, 1929, p. 646. (This species has been synomized at various times under $E$. pseudogula and also under $E$. californiensis).

\section{Family Sciaenidae}

Bairdiella chrysura (Lacépède)

Fowler, H. W., Proc. Acad. Nat. Sci. Phila., Vol. 80, 1928, p. 462.

Umbrina broussonnettii Cuvier and Valenciennes.

Fowler, H. W., Proc. Acad. Nat. Sci. Phila., Vol. 81, 1929, p. 653. (Recorded as Sciaena broussonnettii).

? Stellifer rastrifer Jordan and Eigenmann.

Fowler, H. W., Proc. Acad. Nat. Sci. Phila., Vol. 81, 1929, p. 651. (Locality of specimen not certain).

Iridio bivittata (Bloch)

\section{Family CORIDAE}

In ZooloGiCA, Vol. X, No. 1, p. 203, this species was included, following Meek and Hildebrand's conclusions, under Halichoeres radiatus. Meek and Hildebrand, as has already been noted (ZooloGICA, Vol. XIII, No. 
7,1933, p. 150) were quite wrong in merging these two forms, and it is therefore necessary to reestablish this as a valid Haitian species.

\section{Family ScARIDAE}

Scarus emblematicus Jordan and Rutter

Fowler, H. W., Proc. Acad. Nat. Sci. Phila., Vol. 80, 1928, p. 462 (Recorded as Callyodon emblematicus).

\section{Bollmania litura Ginsburg}

Family GobIIDAE

Ginsburg, I., Smithsonian Misc. Coll., Vol. 91, No. 20, 1935, p. 1.

\section{Family ANTENNARIIDAE}

Antennarius nuttingi Garman

Two specimens of this species from Jeremie, Haiti, are in the collections of the Museum of Comparative Zoology at Cambridge. 


\section{$2 \mathrm{BHL}$ Biodiversity Heritage Library}

Beebe, William and Tee-Van, John. 1935. "Additions to the fish fauna of Haiti and Santo Domingo." Zoologica : scientific contributions of the New York Zoological Society 10(4), 317-319. https://doi.org/10.5962/p.203732.

View This Item Online: https://www.biodiversitylibrary.org/item/207852

DOI: https://doi.org/10.5962/p.203732

Permalink: https://www.biodiversitylibrary.org/partpdf/203732

\section{Holding Institution}

Smithsonian Libraries

\section{Sponsored by}

Biodiversity Heritage Library

\section{Copyright \& Reuse}

Copyright Status: In Copyright. Digitized with the permission of the rights holder

Rights Holder: Wildlife Conservation Society

License: http://creativecommons.org/licenses/by-nc/3.0/

Rights: https://www.biodiversitylibrary.org/permissions/

This document was created from content at the Biodiversity Heritage Library, the world's largest open access digital library for biodiversity literature and archives. Visit BHL at https://www.biodiversitylibrary.org. 